\title{
9. Corporate social responsibility and education reform in Brazil: a critical analysis
}

\section{Heitor Santos}

\section{INTRODUCTION}

This chapter uses the case of the Intel Corporation in Brazil to explore the tensions surrounding the use of corporate funding to promote education reform, making two main contributions to the field of philanthropy in education. First, it adds to the work that has been done by Ball (2012) and other scholars (Peck \& Theodore, 2012; Urry, 2003) towards exploring policy-making outside traditional channels and investigating the structures and nuances of these under-explored 'globalising micro-spaces'. Second, it devotes significant attention to the question of whether it is possible for corporations to make long-term and systemic contributions to the field of education.

While some work has been done when it comes to exploring the role of the private sector in shaping education policy-making in Brazil (e.g., Gandin, 2011; Gandin \& Lima, 2016; Krawczyk, 2014; Mainardes \& Gandin, 2013), not a lot of concerted efforts have been dedicated to exploring the case of science education, especially when it comes to the involvement of multinational corporations. For example, the work of Krawczyk (2014) does a very good job of showing how Brazilian banks and large foundations have been playing an important role in pushing for the implementation of a charter school-like movement in the country. In a similar way, the studies of Avelar and Ball (2017) and Peroni and Caetano (2015) map the key players behind the movement for Brazil's National Learning Standards, alluding to how the emergence of new philanthropy has blurred the lines between the public and the private. Neither of these studies, however, has focused on initiatives of corporate social responsibility steered by multinational corporations, let alone their implications for the field of science education.

The work of Stephen Ball has made significant contributions when it 
comes to suggesting that, as the private sector has gotten more involved with that which was once a sole responsibility of the nation-state, the global structures of policy-making have changed from neat, clear decisionmaking processes to a heterarchy, in which many different stakeholders drive educational change. If multinational corporations were once involved in what has been called 'traditional philanthropy', this model has now been replaced by 'muscular philanthropy', which Smith (2004) describes as the 'intentional and unapologetic use of a foundation's money, position, prestige, and influence to propel change in the face of otherwise effective resistance' (p. 26).

In that sense, it is precisely the fact that corporate reform has assumed more complex and hard-to-map forms that an analysis of these policies requires equally unorthodox methods of analysis. For Peck and Theodore (2012), positivist methodologies pay little attention to 'the social and ideological contexts of the policy-making process, to the politics of knowledge production, or to the more indeterminate zones of policy implementation and practice' (p. 23). The study being presented here follows what Peck and Theodore (2012) call a distended case approach to policy analysis, which 'remains attentive to hierarchical and nodal sources of power, asymmetries in capacities and resources, and so forth' (p. 25).

In light of Peck and Theodore's (2012) call for a judicious combination of observations, documentary analyses and in-depth interviewing, this chapter presents an investigation of the role of the Intel Corporation in promoting education reform in Brazil through its initiatives of Corporate Social Responsibility (henceforth CSR).

For the past two decades, the CSR arm of Intel Brazil has promoted science education reform in the country by developing relationships with local constituencies and periodically taking them to the Intel International Science and Engineering Fair, a science competition that has been sponsored by the company over the past few decades. By funding and encouraging the participation of Brazilian students in the North American competition, it has effectively forced changes in the format of local science competitions in Brazil in order to fit the format and ideology of their U.S. counterparts. This chapter is concerned precisely with mapping the process which allowed for these changes.

This investigation is deeply rooted in my own experience with this corporation and its initiatives in science education. This relationship started as I was a participant in some of the initiatives promoted by this corporation. I then progressed to the position of partner, as the president of a non-profit that directly received money from the Intel Corporation to promote science education in Brazil. It has culminated in my current position as a scholar considering the larger implications of these initiatives in light of existing 
conversations in the academy. However, while the investigation being presented here is profoundly informed by my personal experience over the past years, it is also deeply grounded in research, which included the reviewing of documents, websites and videos related to the programmes investigated here in order to triangulate the findings with other data sources.

Following the logic of my own trajectory with Intel Corporation, this chapter is divided into three separate sections. It starts with a general presentation of the value of Intel-sponsored science fairs for the promotion of science education in Brazil, then moves to an exploration of the sites of persuasion and spaces of mobilisation which have made this reform possible, and ends with a discussion on the repercussions (or side effects) of the reform it promoted.

\section{SCIENCE FAIRS AND THE PANORAMA OF SCIENCE EDUCATION IN BRAZIL}

In order to understand the role of science fairs within the larger structure of science education in Brazil, it is necessary to understand how the Brazilian science curriculum is organised and how the foundations that have been laid down by the federal government have created the conditions that permitted these initiatives to flourish. An understanding of the basic structure of science teaching in Brazil should bring to light, on the one hand, how science fairs might be alternatives to meet existing needs in the education system, and, on the other hand, how these movements might be promoting a conception of science that challenges what has been established by the existing legislation as an authentically Brazilian science education.

The science curriculum in Basic Education in Brazil is regulated by the Parâmetros Curriculares Nacionais, or National Curricular Parameters (henceforth NCPs). The National Curricular Parameters for Natural Sciences were published in 1998 by Brazil's Ministry of Education as an attempt to provide teachers with a basis for how to develop their curricula. The NCPs were published as a response to a 1996 law which determined that 'Os currículos da educação infantil, do ensino fundamental e do ensino médio devem ter base nacional comum, a ser complementada, em cada sistema de ensino e em cada estabelecimento escolar, por uma parte diversificada, exigida pelas características regionais e locais da sociedade, da cultura, da economia e dos educandos' [The lower primary, primary, and secondary school curricula must have a national common base, to be complemented, in each education system and in each educational establishment, by a diversified part, demanded by the regional and local 
characteristics of the society, the culture, the economy, and the pupils] (LDBEN, 1996, Art. 26).

Brazil's Natural Science NCPs propose a fairly holistic understanding of the meaning and purpose of science. The official document says:

Considering the mandatory nature of middle school in Brazil, one cannot think of the teaching of natural sciences as being preparatory, only focused on a distant future. The student is not just a future citizen, but it is already a citizen today, and in this sense, the process of knowing science is about broadening students' current ability to participate socially and develop mentally, so that they can exercise their citizenship fully. ${ }^{1}$ (Ministry of Education and Sport, Secretariat of Basic Education, 1998, p.23)

Brazil's conception of the value of science teaching, therefore, is very much related to the need to prepare citizens to participate fully in a democracy. In that sense, there is a way in which policy-makers seem to understand that preparing students to master science is a process that also gives them the skills that they need to become better citizens.

At first glance, it is clear that Brazilian education is rooted in a progressive understanding of the value of science, which is more concerned with developing competencies than with covering a particular amount of subject matter. In practice, however, there are other existing structures that have prevented Brazilian schools from teaching in a way that is coherent with the ideas proposed by the NCPs. Among other things, the structure of admissions exams to higher education has forced teachers to apply a onesize-fits-all approach which is focused primarily on preparing students to ace standardised tests rather on understanding science in a contextualised manner (Carvalho \& Rezende, 2013).

It is within this context of a broken science curriculum that science fairs emerge as important opportunities for students to explore science with more autonomy, an essential aspect for the development of higher levels of interest in science (Renninger \& Hidi, 2016). Taking into consideration the clear need for a reform in the science curriculum in Brazil, Intel's investment in science education in the country tackles a legitimate need for new avenues to explore science. After all, science fairs create a space for students to develop important analytical skills while also pursuing their own interests.

1 This is a translation of the following:

Considerando a obrigatoriedade do ensino fundamental no Brasil, não se pode pensar no ensino de Ciências Naturais como propedêutico ou preparatório, voltado apenas para o futuro distante. $\mathrm{O}$ estudante não é só cidadão do futuro, mas já é cidadão hoje, e, nesse sentido, conhecer Ciência é ampliar a sua possibilidade presente de participação social e desenvolvimento mental, para assim viabilizar sua capacidade plena de exercício da cidadania. (Ministry of Education and Sport, Secretariat of Basic Education, 1998, p. 23) 
While it is not the oldest or largest, the Brazilian Science and Engineering Fair (FEBRACE) is undoubtedly the most famous science fair in Brazil. In addition to being the science fair with the most funding, it also receives a disproportionately larger amount of media coverage than other science fairs, being the only Brazilian science fair to actually have a nation-wide TV commercial for it. It was launched in 2003 by Dr Roseli de Deus, a professor at the School of Engineering of the University of São Paulo, where the science fair is hosted each year. A few years before founding FEBRACE, Dr de Deus was invited by Intel Brazil to visit the Intel International Science and Engineering Fair (Intel ISEF), organised by the Society for Science and the Public (SSP), a U.S.-based non-profit 'focused on promoting the understanding and appreciation of science and the vital role it plays in human advancement: to inform, educate, and inspire' (Society for Science and the Public, 2018, para. 1). While the International Science and Engineering Fair is promoted and hosted by SSP, Intel Corporation has been its main sponsor since 1997.

Parallel to Intel ISEF, Intel Corporation has hosted the Intel Educator Academy, an event that brings together policy-makers and important stakeholders in the field of science education around the globe to learn more about the structure of Intel ISEF, exchange ideas and make plans and commitments that can be brought back to their countries. While the structure of the Intel Educator Academy will be further discussed in the following section, it was through the Educator Academy that Dr de Deus became familiar with the format of U.S. science fairs and extracted most of the structure that would later guide the way FEBRACE is organised. In that sense, Intel's support was instrumental in promoting the creation of what is now one of the most important science competitions in Brazil.

FEBRACE's main contribution to Brazilian education is very wellsynthesised in its three main goals: (1) To stimulate new vocations in science and engineering through the development of creative and innovative projects; (2) To bring public and private schools closer to universities, creating opportunities for spontaneous interactions among students and teachers with the community of the University (students, faculty, and staff) for a better understanding of the role of universities in teaching, research, culture and extension courses; (3) To create opportunities for Brazilian pre-college students to be in contact with different cultures and be closer to well-known scientists² (Feira Brasileira de Ciências e Engenharia, 2018).

2 This is a translation of the following points:

Estimular novas vocações em Ciências e Engenharia através do desenvolvimento de projetos criativos e inovadores. 
In light of what has been seen so far, a few aspects seem worthy of consideration. First, the experience of going to a science fair like FEBRACE certainly places a career in science and engineering in the realm of possibility for many students. Angela Duckworth's (2016) research on grit has already suggested that people have a higher tendency to work harder and continue to persist on their pursuits if they are first given the possibility of exploring it loosely. Additionally, Depieri's (2014) work has shown that students involved in science fairs are more likely to demonstrate more positive attitudes towards pursuing a career in engineering than students who do not participate in these events. In that sense, just by virtue of being separate from the traditional school curriculum, science fairs like FEBRACE provide students with the opportunity to pursue their interest in science while also changing their perceptions towards the pursuit of a career in this area.

Additionally, science fairs certainly bring students closer to universities, first, because of the very place in which some of these events are located. Students coming to FEBRACE have the opportunity to have lunch at some of the dining halls of the University of São Paulo, one of the most distinguished universities in South America. Second, they are exposed to university students and faculty, since project judges are usually $\mathrm{PhD}$ students and professors at the University of São Paulo, which gives students the opportunity to talk about their science research with some of the country's most high-calibre researchers.

Finally, FEBRACE also does an incredible job when it comes to creating opportunities for Brazilian students to be in contact with different cultures. By bringing together students from all over the country and adding specific events in its schedule to promote cultural interchange among them, the science fair truly gives students a new perspective on the possibilities available to them. Many states and local municipalities have allocated specific funding to allow public school students to attend these national science fairs. In that sense, the very act of going to an event somewhere else in the country is a life-changing experience for many students, many of which are leaving their cities for the first time.

In summary, in light of the existing structure and need for reform in the science curriculum in Brazil, science fairs are important additions

Aproximar as escolas públicas e privadas das Universidades, criando oportunidades de interação espontânea entre os estudantes e professores das escolas com a comunidade universitária (estudantes, professores, funcionários), para uma melhor compreensão dos papéis das universidades em Ensino, Pesquisa, Cultura e Extensão.

Criar uma oportunidade para jovens pré-universitários brasileiros entrarem em contato com diferentes culturas e estarem próximos de reconhecidos cientistas. (Feira Brasileira de Ciências e Engenharia, 2018) 
to Brazilian education, and they encourage students to have a positive attitude towards science, in addition to providing them with opportunities which they do not traditionally have in the science classroom, such as cultural exchange, interactions with high-level researchers and the pursuit of their own interests in the area. The following section is dedicated to exploring how these science competitions are formed, with particular attention to the role of the Intel Corporation in creating the spaces of policy mobilisation that bring different stakeholders into the conversation.

\section{INTEL CORPORATION AND SCIENCE EDUCATION}

Having considered some of the products of Intel's investment in science education in Brazil, it is now relevant to take a close look at the ways in which these policies came to be implemented. It has already been said that the Intel Educator Academy played an important role in encouraging the foundation of FEBRACE, which is now Brazil's most well-known science fair. This section is particularly concerned with analysing how events like the Intel Educator Academy function as spaces of policy mobilisation, which eventually lead to the implementation of competitions like FEBRACE.

Understanding Intel's strategy for mobilising policy is essential, not only because it brings to light the 'social processes through which policy rationales, rationalities, and routines are constructed and reconstructed, made and unmade' (Peck \& Theodore, 2012, p.24), but because these social processes are also crucial when it comes to defining the parameters through which policy will be implemented. That is, not only is muscular philanthropy concerned with promoting change, but it is concerned with promoting change under a very particular framework, a process which David Harvey (2005) calls the 'construction of consent' (p. 39).

Talking about this 'new philanthropy', Ball (2012) highlights the importance of conferences such as the Clinton Global Initiative University conference, arguing that they function as 'new sites of policy mobilization and "globalizing micro-space" (p. 66):

These sites, events and activities, or 'moments of encounter' (Amin \& Thrift, 2002 , p. 30), and the social networks which join them up, operate between and beyond traditionally defined arenas of policy formulation, such as localities, regions and nations - on a different scale and in different spaces. (Ball, 2012, p. 66)

Indeed, the context of the Intel Educator Academy is very much that of creating a globalising micro-space - an essential factor in the creation of 
these new policy frameworks that foster the neoliberal imaginary. It is through the Educator Academy that Intel recruits and convinces policymakers and stakeholders from countries all over the world that their system of science education is worth being implemented. And this process of construction of consent happens not only through the event itself but also the perks that come with it - guests stay in expensive hotels, eat in expensive restaurants, meet important policy-makers and, above all, network among themselves (Intel, 2017; U.S. Chamber of Commerce Foundation, 2019).

At each edition of the Intel Educator Academy, each participating country brings stakeholders (science fair directors, government officials, non-profit leaders, etc.), who work in groups, not only attending talks but also socialising and discussing the implications of the experience at the Educator Academy for their countries. Once these leaders come back to their respective countries, the local education managers for Intel Corporation do the work of ensuring that the relationships that were built at these conferences ultimately culminate in governmental and community buy-in for their programmes. This is where local non-profit organisations (at least in the case of Brazil) do the rest of the work: if Intel takes these executives abroad to show them the model, these local organisations do the groundwork by meeting with teachers and ensuring that the projects that they are teaching in schools fit with the model that is expected of them. One of the best examples for this case is the Secretariat of Education of the Municipality of Recife. Their local representative participated at the Intel Educator Academy in May 2015, the same year I participated as a guest speaker from Intel Brazil. Upon our return to Brazil, my local non-profit worked with educators from Recife's Secretary of Education in order to launch its first local science fair (Prefeitura do Recife, 2015).

Just as events like the Educator Academy are used as sites of persuasion so that stakeholders can be convinced of the importance of promoting science in their countries, it is also important to explore the implications of this policy implementation on the ground. That is, once consensus is constructed and stakeholders choose to start a movement that promotes science in their countries, they end up getting more than international travel and fine dining experiences. In the case of Brazil, the importation of the Intel ISEF model of science fairs had several implications for the implementation of such a model in the country. Three deserve particular attention: the propagation of a meritocratic view of science fairs; a positivist, product-oriented understanding of the value of science; and very strict guidelines for science projects.

First, the way in which Intel ISEF recruits its participants and carries out its own activities makes it clear that it is trying to defend the idea that students who have made it this far are part of an elite. One of the most 
evident ways in which this message gets communicated is in the discourse used by the presenters at the opening ceremony of the science fair. Students are often complimented with phrases such as 'the brightest young minds in the world', which was written on posters all over the Phoenix Convention Center during Intel ISEF 2013. It is not just the language that contributed to the formation of this elite. At the 2011 edition of Intel ISEF, SSP closed the entire Hollywood Universal studios and provided free, unlimited access to the park and its food courts to all Intel ISEF finalists.

FEBRACE also has a separate system for selection of Intel ISEF finalists, which is made evident by the fact that the best performing projects at FEBRACE are not always the ones selected to be finalists at ISEF. During both my experiences as a finalist at FEBRACE in 2010 and 2012, I was explicitly approached by judges who introduced themselves as being part of a committee which was charged with selecting projects for ISEF. The concerns of these judges differed from those of the other regular judges in two particular aspects: my ability to present my project in English and the existence of statistical evidence for my research findings. These serve to show a concern for selecting projects which would be considered competitive at ISEF.

This focus on competition is certainly not coherent with the values put forth by the NCPs, which suggest that the focus of science learning should be for people to strengthen their bonds with each other and understand the impact of their actions on the environment. It is also not in tune with the purpose of the national fund for science competitions deployed by the federal government, as per their own official document (see Ministry of Education and Sport, Secretariat of Basic Education, 2006), which maintains a progressive understanding of the value of these competitions by asserting that their main purpose is to allow students to be in contact with the public and share their science discoveries in the classroom.

In that sense, the fact that FEBRACE is so particular in its system for selecting projects that get to participate in ISEF also raises a question of equity in access to these competitions. Who gets to participate in competitions like ISEF and what type of science does one need to produce in order to qualify and have access to that experience? And once students figure out the model of science that is validated by this competition in particular, what does it say about other ways of doing science or the epistemological plurality that these science competitions are supposed to foster?

Unsurprisingly, FEBRACE's model of what good science and innovation looks like is very much in line with the model proposed by Intel - the very $\log$ o of the science fair is a machine that makes an allusion to a production of science that is not palpable or cannot be easily translated into a product. Even though having a good engineering project most of the 
times guarantees that someone will get a spot as a finalist at Intel ISEF, the same is not true for projects in the humanities and social sciences, where a lot more statistical and quantifiable results would be necessary.

The third and final implication of adopting Intel's framework for science teaching is that, since projects selected to participate at Intel ISEF need to follow specific rules for how the research is conducted and approved, all local Brazilian science fairs which intend to do something similar need to adopt the same rules. The problem, however, is that these rules are not always easily translated to a country which has an education system that is so strict both in the number of hours that are allocated for students to be working with teachers and in the type of subject matter that teachers should be covering in their lessons.

One example is the requirement for the number of students involved in one particular project. Because Intel ISEF determines that group projects be planned and carried out by groups of not more than three students (Society for Science and the Public, 2019), partner science fairs like FEBRACE have established the same rules so that all of their projects are eligible for the U.S. competition. This requirement, however, is extremely unrealistic for most Brazilian schools, where natural science is mandatory in the curriculum (Ministry of Education, 2019) and teachers have anywhere between 10 and 30 students in a classroom (Observatório da Criança e do Adolescente, 2019). In the context of the United States, where students may opt to matriculate into science classes, it might be more realistic to create requirements in which smaller groups of students would be able to work with the science teacher to conduct their own research. In the case of Brazil, however, from the perspective of equity, a science teacher who does not get paid for extracurricular programming would have to find a way to accommodate 10 to 15 groups of three students if science projects were to align with the Intel ISEF requirements.

Other examples are the forms required of students so that they can do specific types of research. Intel ISEF (and, consequently, FEBRACE) requires all student project proposals to be read and approved by a Scientific Review Committee (SRC), which would be the school's equivalent of an Institutional Review Board (IRB) (Feira Brasileira de Ciências e Engenharia, 2019; Society for Science and the Public, 2019). While the structure of an SRC is very warranted, especially given U.S. laws which require students be working in the right conditions in order to avoid any sort of liability to the school, its requirements are often very unrealistic for the average Brazilian public school. For example, it is very hard for schools to have either a medical doctor or someone with a master's degree in the area in which the project is written, so that they can review the project proposal and approve it beforehand. 
It is important to notice that Intel's way of structuring science competitions did not just affect the way science fairs in Brazil were structured, including what they valued about science, but it also excluded those that chose not to abide by its standards. One of the best examples of this case is Ciência Jovem, a science fair that is much older than FEBRACE and other Intel-sponsored science fairs. The science fair's website describes its mission as 'que professores e alunos se sintam estimulados a elaborar e executar trabalhos científicos de forma integrada ao currículo da escola' [stimulating teachers and students to elaborate and execute science projects in a way that is integrated to the school curriculum] (Espaço Ciência, 2018, para. 4). Ciência Jovem allows its science project entries to include entire classrooms of students, and unlike FEBRACE, there is a stronger focus on the process of discovering the scientific method and its procedures than on the actual need for students to make a tangible and measurable contribution to the scientific community. However, because of its more relaxed rules towards the science projects it receives, this science fair is also limited in its ability to send students to compete in larger competitions like FEBRACE, since many of its projects do not fit the requirements for team size or the forms that need to be filled out. Consequently, some of the projects that participate in this alternative movement will never qualify to have access to the opportunities afforded by competitions like FEBRACE.

What is clear, then, is that while Intel's initiatives come with the goal of addressing a real need in the Brazilian science curriculum, the reverberations of its reforms go beyond the establishment of a movement for precollege science research. Instead, Intel's investment in science education in Brazil has effectively challenged the foundations of the science curriculum in Brazil, introducing not only a new way of understanding the value of science but also a new way of structuring science competitions, which reverberated in such a way that excluded the science fairs that did not abide by its strict standards. The following section takes this discussion to the next level by further exploring the implications of Intel's investment in science education in Brazil, paying close attention to the sustainability of the changes it promoted.

\section{THE LEGACIES OF CORPORATE EDUCATION REFORM}

Having understood the ways in which science fairs come to meet existing needs in the Brazilian education system and the mechanisms utilised by Intel as a multinational corporation to include them in the policy agenda, a third and final issue needs to be taken into consideration, which 
is the inconsistency of the funding support provided by multinational corporations and the implications of an eventual divestment for the local movements in science education. In other words: what happens when the implemented policy is no longer of interest to the corporations that worked to put them in place, and what does that mean for the very legitimacy of initiatives of CSR?

On 14 February 2017, The New York Times published an article entitled 'Intel Drops Its Sponsorships of Science Fairs, Promoting Identity Crisis'. In addition to discussing the history of the relationship between Intel and ISEF, the article narrated a discussion between Brian Krzanich, Intel's chief executive, and Craig Barret, a former chief executive at the same company:

The Intel decision provoked a sharp difference of opinion between Brian Krzanich, Intel's current chief executive, and Craig R. Barrett, a former Intel chairman and chief executive.

Mr. Krzanich has told colleagues privately that the science fairs were the fairs of the past and had become tilted to life sciences and biotechnology, not primary fields for Intel, according to two people who are not authorized to speak publicly for the company.

Mr. Barrett disagreed. In an email, he said, 'you might instead conclude that Intel is a company of the past, just like Westinghouse when they dropped sponsorship of the national science fair in 1998'.

Mr. Barrett, who is on the board of the Society for Science [for Science and the Public], also said that all of science has become data-driven and computational, so Intel has a stake in nurturing youthful innovators in all scientific disciplines, including the life sciences. (Lohr, 2017)

What the excerpt above shows is that there is a way in which the investment in science education through programmes of CSR, at least in this particular case, is not necessarily something that envisions a larger, common goal of improving science education worldwide or contributing to the creation of a science, technology, engineering and mathematics pipeline. Instead, science fairs are considered a means to an end - an investment that is only considered worthwhile insofar as it contributes to the company's private interests. This assertion actually blurs the line between CSR, which was once assumed to be devoid of an interest in a direct return, and philanthrocapitalism, or 'the New Philanthropy', as Ball has named it, since benefactors are now becoming consumers of the social investment or at least make their policy decisions as if it were so (Ball, 2012).

The consequences of Intel pulling back from investing in science fairs are many. FEBRACE started a social media campaign called '\#febracevaleapena' or 'FEBRACE is worth it'. Since 2018, the University of São Paulo has also suspended its local science fair (MOP - Mostra Paulista 
de Ciências e Engenharia), also due to the lack of funding for science competitions.

One of the main issues to be considered here is the fact that, despite placing so many of its resources towards ensuring that its movement for science fairs in Brazil would serve as a model for all other initiatives in science education and ensuring that there would be government buy-in, Intel did not place the same amount of effort into ensuring that the movements it was establishing in Brazil would be self-sustaining in the long-term. Despite decades of investment in science fairs in Brazil, the impact of Intel's initiative was extremely limited, since it did not ultimately promote a sustainable change for the issue it proposed to improve - that is, the existing deficiency in the science curriculum in Brazil.

\section{CONCLUDING REMARKS}

There is nothing objectively wrong with the involvement of the private sector when it comes to improving science education, in Brazil or anywhere else in the world. As Ferguson (2010) suggests, one needs to be careful with the blatant criticism of neoliberal practices, especially when the involvement of the private sector provides people with support and resources that the nation-state has historically failed to provide. It is equally important, however, to be careful not to interpret welcoming of the influence of the private sector as a free pass for it to change the way the education system is run.

It would also be extremely naive to assume that every movement for improving an education system needs to be necessarily rooted in the cultural rituals and traditions of a country. After all, acknowledging the global nature of education and the global politics of educational borrowing and lending necessitates that we also agree that certain changes that come from the global to the local can be extremely valid, even if they implicate certain ruptures with local customs. It would be simplistic to assume such a critical position that asserts that the West has nothing to contribute to the Global South.

In the case of science education, there is a way in which Intel's investment in Brazil has worked to implement a seriously ground-breaking way of thinking about school science. Even though the Brazilian education system is progressive and social constructivist in nature, other underlying circumstances for the context of science teaching, such as the lack of highly qualified teachers ascending to the teaching profession and a traditionalist, content-based system of admission to higher education, has prevented these progressive ideals from being put into practice. In that sense, Intel's 
investment in science has truly created avenues for students to explore and develop their interest in science which would not exist otherwise.

However, despite the clearly positive consequences of Intel's investment in initiatives of science education, two important issues come to the surface. First, it has become clear how CSR, particularly from the perspective of North American corporations, effectively functions as a U.S. imperial project abroad - changing ideologies and establishing relationships of dependency that ultimately reinforce the neoliberal imaginary, as conceived in the United States. Second, and equally important, is that one needs to ask what happens to these initiatives of science education when private corporations stop supporting them financially, for one reason or another. That is, not only have these multinational corporations contributed to the creation of a system that is not necessarily in tune with the local concept of nationhood, but they have also failed to create selfsustaining, long-lasting systems. No private corporation can guarantee their perennial support for certain initiatives, but have they worked with local organisations to support the building of such structures? On the one hand, one is left wondering: what would have happened if, instead of investing its time, money and energy into replicating a U.S. model of science teaching abroad, Intel had invested its money in educating teachers and reforming the science curriculum in Brazilian schools in order to eliminate the existing inequalities in access to resources? On the other hand, an equally valid question comes to mind: would Intel ever make such an investment, knowing that its outcomes might not be of direct interest to the company?

The paradox that lies between these two sets of questions lands precisely in line with the question that this chapter posed: is it possible for corporations to make long-term and systemic contributions to the field of education?

The key takeaway from this reflection lies not only in the unceasing critical examination of the role of private corporations but precisely in the need for examples of adequate, sustainable and respectful experiences of CSR which might serve as models for sustainable corporate education reform, if such a thing is at all possible.

\section{REFERENCES}

Avelar, M., \& Ball, S. J. (2017). Mapping new philanthropy and the heterarchical state: The movement for the National Common Base in Brazil. International Journal of Educational Development. Advance online publication. https://doi. org/10.1016/j.ijedudev.2017.09.007 
Ball, S. J. (2012). Global Education Inc: New policy networks and the neo-liberal imaginary. Abingdon, UK: Routledge.

Carvalho, R. C., \& Rezende, F. (2013). Políticas curriculares e qualidade do ensino de ciências no discurso pedagógico de professores de nível médio [Curriculum policies and quality of science education in teachers' pedagogical discourse]. Ciência \& Educação, 19(3), 555-571. https://doi.org/10.1590/S151673132013000300005

Depieri, A. A. (2014). A engenharia sob a ótica dos pré-universitários e o impacto das feiras de ciências [Engineering through pre-university students' eyes and the impact of science fairs] (Doctoral dissertation). https://doi.org/10.11606/T.3.2014. tde-25032015-165603

Duckworth, A. (2016). Grit: The power of passion and perseverance. New York, NY: Scribner/Simon \& Schuster.

Espaço Ciência. (2018). Ciência Jovem. Retrieved June 30, 2019, from http://www. espacociencia.pe.gov.br/?atividade $=$ ciencia-jovem

Feira Brasileira de Ciências e Engenharia. (2018). O que é a FEBRACE? [What is FEBRACE?]. Retrieved June 30, 2019, from https://febrace.org.br/o-que-e-afebrace/\#.XARZBBNKjBI

Feira Brasileira de Ciências e Engenharia. (2019). Regras de Segurança [Safety rules]. Retrieved June 30, 2019, from https://febrace.org.br/regras-de-seguranca/\#. XD-zo89KjBI

Ferguson, J. (2010). The uses of neoliberalism. Antipode, 41, 166-184. https://doi. org/10.1111/j.1467-8330.2009.00721.x

Gandin, L. A. (2011). Porto Alegre as a counter-hegemonic global city: Building globalization from below in governance and education. Discourse: Studies in the Cultural Politics of Education, 32(2), 235-252.

Gandin, L. A., \& Lima, I. G. (2016). A perspectiva de Michael Apple para os estudos das políticas educacionais [Michael Apple's contributions to research on educational policies]. Educação e Pesquisa - Revista da Faculdade de Educação da USP, 42, 651-664.

Harvey, D. (2005). A brief history of neoliberalism. Oxford, UK: Oxford University Press.

Intel. (2017, September 28). What is the Intel ISEF Educator Academy? Retrieved June 30, 2019, from https://www.intel.com/content/www/us/en/support/articles/ 000022934/programs.html

Krawczyk, N. (2014). Ensino médio: empresários dão as cartas na escola pública [High school: businessmen run show in public schools]. Educação \& Sociedade, 35(126), 21-41. https://doi.org/10.1590/S0101-73302014000100002

LDBEN (1996). Lei 9.394/1996. Estabelece as Diretrizes e Bases da Educação Nacional. D.O. DE 23/12/1996, P. 27833. (2006). Retrieved June 30, 2019, from http://www.planalto.gov.br/ccivil_03/leis/L9394.htm

Lohr, S. (2017, February 14). Intel drops its sponsorship of science fairs prompting an identity crisis. The New York Times. Retrieved June 30, 2019, from https:// www.nytimes.com/2017/02/14/technology/intel-drops-its-sponsorship-of-sciencefairs-prompting-an-identity-crisis.html

Mainardes, J., \& Gandin, L. A. (2013). Contributions of Stephen J. Ball to the research on educational and curriculum policies in Brazil. London Review of Education, 11, 256-264.

Ministry of Education. (2019). Base Nacional Comum: 4.3. Ciências da Natureza [National Common Core: 4.3. Natural Sciences]. Retrieved June 30, 2019, from 
http://basenacionalcomum.mec.gov.br/abase/\#fundamental/a-area-de-cienciasda-natureza

Ministry of Education and Sport, Secretariat of Basic Education. (1998). Parâmetros curriculares nacionais terceiro e quarto ciclos do ensino fundamental: introdução aos parâmetros curriculares nacionais [National curricular parameters third and fourth cycles of elementary education: Introduction to the national curricular parameters]. Brasília, Brazil: Author.

Ministry of Education and Sport, Secretariat of Basic Education. (2006). Programa Nacional de Apoio às Feiras de Ciências da Educação Básica Fenaceb [National Program of Support to Science Fairs in Basic Education Fenaceb]. Brasília, Brazil: Author.

Observatório da Criança e do Adolescente. (2019). Média de alunos por turma no Ensino Médio [Average number of students per class in secondary school]. Retrieved June 30, 2019, from https://observatoriocrianca.org.br/cenario-infan cia/temas/ensino-medio/652-media-de-alunos-por-turma-no-ensino-medio?filters $=1,826$

Peck, J., \& Theodore, N. (2012). Follow the policy: A distended case approach. Environmental Planning A: Economy and Space, 44(1), 21-30. https://doi.org/10. 1068/a44179

Peroni, V. M. V., \& Caetano, M. R. (2015). O público e o privado na educação: projetos em disputa? [Public and private education: competing projects?]. Revista Retratos da Escola, 9(17), 337-352.

Prefeitura do Recife. (2015, December 19). Melhores projetos da rede municipal do Recife são premiados na Feira de Conhecimentos [Best projects from the municipal education system of Recife awarded at Science Fair]. Retrieved June 30, 2019, from http://www2.recife.pe.gov.br/noticias/19/12/2015/ melhores-projetos-da-rede-municipal-do-recife-sao-premiados-na-feira-de

Renninger, K. A., \& Hidi, S. (2016). The power of interest for motivation and learning. New York, NY: Routledge.

Smith, R. (2004). Muscular philanthropy. Education Week, 11 February, 23(2), 26. Retrieved June 30, 2019, from https://www.edweek.org/ew/articles/2004/02/11/22 smith.h23.html

Society for Science and the Public. (2018). Mission \& history. Retrieved June 30, 2019, from https://www.societyforscience.org/mission-and-history

Society for Science and the Public. (2019). Rules for all projects. Retrieved June 30, 2019, from https://student.societyforscience.org/rules-all-projects

Urry, J. (2003). Social networks, travel and talk. British Journal of Sociology, 54(2), 155-175. https://doi.org/10.1080/0007131032000080186

U.S. Chamber of Commerce Foundation. (2019). Best Partnership Award finalist: Intel and SSP. Retrieved June 30, 2019, from https://www.uschamberfoundation. org/article/best-partnership-award-finalist-intel-and-ssp 